
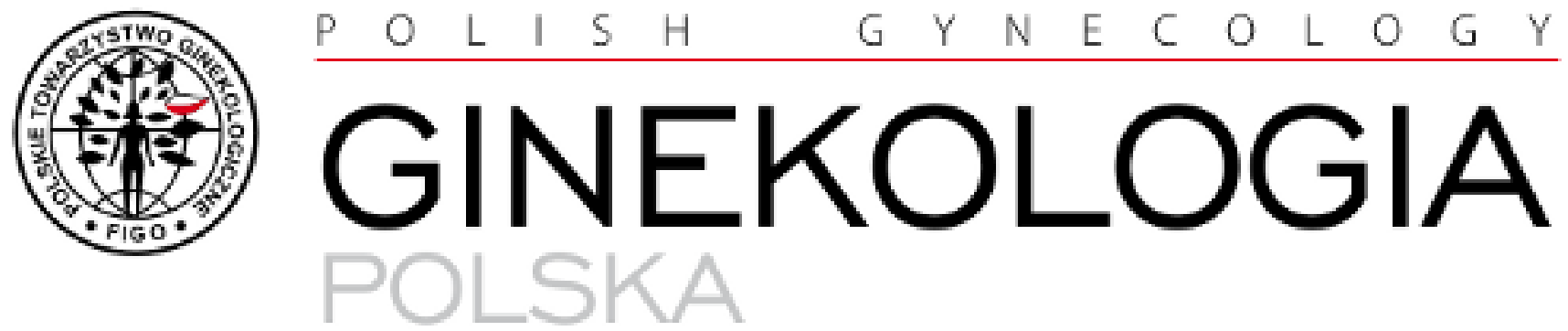

ORGAN POLSKIEGO TOWAAZYSTWA GINE KOLOGICZNEGO

THE OFFICIAL JOURNAL OF THE POLISH GYNECOLOGICAL SOCIETY

ISSN: 0017-0011

e-ISSN: $2543-6767$

\title{
The perinatal outcomes of frozen-thawed blastocyst transfer are better than fresh blastocyst transfer: a systematic review and meta-analysis
}

Authors: Caihong Li, Dongkai Cheng, Hongjun Yu, Chunyi Li, Peng Li, Peng Xu

DOI: 10.5603/GP.a2021.0159

Article type: Research paper

Submitted: $2020-02-11$

Accepted: $2020-05-12$

Published online: 2021-08-03

This article has been peer reviewed and published immediately upon acceptance.

It is an open access article, which means that it can be downloaded, printed, and distributed freely, provided the work is properly cited.

Articles in "Ginekologia Polska" are listed in PubMed. 


\title{
ORIGINAL PAPER/OBSTETRICS
}

\section{The perinatal outcomes of frozen-thawed blastocyst transfer are better than fresh blastocyst transfer: a systematic review and meta-analysis}

\author{
Caihong Li, Dongkai Cheng, Hongjun Yu, Chunyi Li, Peng Li, Peng Xu
}

\section{Corresponding author:}

Caihong Li

e-mail: licaihong6812@126.com

\begin{abstract}
Objectives: Transfer of cryopreserved-warmed blastocysts is common in the practice of in vitro fertilization. The purpose of the study is to examine the available evidence and determine whether cryopreservation of blastocysts and subsequent frozen blastocyst transfer (BT) result in better outcomes than fresh BT.
\end{abstract}

Material and methods: Related studies comparing outcomes of in vitro fertilization (IVF) cycles between fresh and frozen BTs were retrieved from Medline, Cochrane Central Register of Clinical Trials, EMBASE, DARE, and CINAHL through March 2020. The outcomes of interest were preterm birth, extremely preterm birth, small for gestational age, large for gestational age, low birth weight, extremely low birth weight, caesarean section, perinatal mortality and preeclampsia. The analysis was performed using Rev Man 5.1 software. Risk ratios (RRs) and risk differences were calculated with 95\% confidence intervals, to evaluate the results of each outcome. The quality of the referenced studies was assessed using the Newcastle-Ottawa scale (NOS) checklists.

Results: Nine studies with 42,342 women incorporated in this meta-analysis. The incidence of preterm birth $(\mathrm{RR}=0.89,95 \% \mathrm{CI}: 0.82,0.97)$ and small for gestational age $(\mathrm{RR}=0.55$, 95\% CI 0.41-0.74) was low in frozen BT group. There was no significant difference in the risk of low birth weight $(\mathrm{RR}=0.89,95 \% \mathrm{CI}: 0.67,1.19)$ and perinatal mortality $(\mathrm{RR}=1.47$, 95\% CI: 0.85, 2.55) between frozen-thawed and fresh BT. Singleton pregnancy after frozen BT was associated with higher large for gestational age (RR = 1.47, 95\% CI: 1.37, 1.57), 
caesarean section rates $(\mathrm{RR}=1.24,95 \% \mathrm{CI}: 1.13,1.36)$ and preeclampsia compared with fresh BT $(\mathrm{RR}=1.85,95 \% \mathrm{CI}: 1.22,2.82)$.

Conclusions: The frozen BT results in better perinatal outcomes compared with that of fresh BT. Furthermore, comprehensive randomized clinical trials comparing freeze-all with fresh BT cycles are needed to draw sound conclusions.

Key words: fresh blastocyst transfer; frozen blastocyst transfer; obstetric outcomes; perinatal outcomes 


\section{INTRODUCTION}

During the past decade, frozen-thawed embryo transfers (FETs) have contributed to an increase in the proportion of live deliveries that occur following the use of assisted reproductive technology [1, 2]. However, the relative effectiveness and safety of in vitro fertilization (IVF) treatment with the freeze-all strategy compared to the conventional IVF/ICSI (intracytoplasmic sperm injection) strategy is unclear. A previous systematic review [3] reported that a freeze-all strategy was associated with higher ongoing and clinical pregnancy rates and lower miscarriage rates than the conventional IVF/ICSI strategy. However, recently a Cochrane systematic review noted that there was no clear evidence of a difference between the freeze-all strategy and the conventional IVF/ICSI strategy in cumulative live birth rates per woman, but the prevalence of ovarian hyper-stimulation syndrome (OHSS) appeared to be lower after the freeze-all strategy [4].

In recent years, with the refinement of techniques for blastocyst culture and in compliance with the guidelines for reducing the risk of multiple pregnancies [5], the application of single blastocyst transfer has become increasingly popular. Compared with cleavage stage embryo transfer, blastocyst transfer (BT) has been shown to increase delivery rate, particularly in younger women [6], which allows for an improved selection of potentially viable embryos at this late stage of development, and thus results in better live birth rates [7].

There are reviews and meta-analysis such as fresh versus frozen embryo transfers focused on the cleavage embryo and frozen blastocyst versus cleavage-stage embryo transfer $[8,9]$. However, there was only one randomized controlled trial that compared the obstetric and perinatal outcomes between frozen BT and fresh BT [10]. Therefore, a meta-analysis is urgently needed to compare the obstetric and perinatal outcomes in singleton pregnancies between frozen BT and fresh BT as supplementary evidence. The present study aimed to evaluate if frozen BT has a better perinatal outcome than fresh BT of singleton pregnancies.

\section{MATERIAL AND METHODS}

\section{Data sources and searches}

Two authors independently searched Medline, Cochrane Central Register of Clinical Trials, EMBASE, DARE, and CINAHL from each database's inception to the end of March 2020. We used the following keywords to search the literature: blastocyst, vitrification, embryo transfer outcome, preterm birth, extremely preterm birth, small for gestational age, large for gestational age, low birth weight, and extremely low birth weight. We also hand 
screened references of relevant review articles to identify other potential studies. The disagreement was settled by group discussions. Duplicated studies were carefully considered, and comprehensive and high-quality studies were included.

\section{Study selection}

Inclusion criteria: An initial scoping exercise found only one randomized controlled trial. The remaining studies included in this paper were observational studies (published), the main outcome measure of these studies were obstetric and perinatal outcomes in singleton pregnancies between fresh BT and frozen BT.

Exclusion criteria: If the outcome measures were not obstetric and perinatal outcomes, or could not distinguish between singleton and twin outcomes, the study was excluded.

\section{Exposure in the included studies}

In the included studies, blastocysts were frozen by vitrification or slow-freezing techniques on day five or day six. Frozen blastocysts were thawed and transferred in natural cycle or artificial cycle.

\section{Outcome measures}

The following outcome measures were included: preterm birth (delivery before 37 weeks), extremely preterm birth (delivery before 32 weeks), low birth weight (birth weight < 2,500 g), extremely low birth weight (birth weight $<1,500 \mathrm{~g}$ ), small for gestational age, large for gestational age, caesarean section (both emergency and elective), perinatal mortality and preeclampsia.

\section{Statistical analysis}

For each result, data were extracted in $2 \times 2$ tables. Meta-analysis was conducted wherever appropriate. Risk ratios (RRs) with 95\% confidence intervals (CI) were used to describe the dichotomous outcomes of each study. We used forest plot to evaluate the heterogeneity of the exposure effects graphically and applied $l^{2}$ to assess the heterogeneity among the studies. When $\mathrm{l}^{2}$ is higher than $50 \%$, sensitivity analysis was performed by altering the fixed-to-random effect analysis. We used Rev Man 5.1 software (The Nordic Cochrane Centre, The Cochrane Collaboration 2011) to perform analysis.

Two authors did quality assessment independently of each observational study. Any disagreements about the type and quality of the studies were resolved through group 
discussions. Newcastle-Ottawa scale (NOS) checklist were used to assess the quality of observational studies. If the NOS score of the study $\geq 6$, it was considered a high-quality study.

\section{Assessment of reporting biases}

Funnel plots were constructed to test for reporting bias when at least three studies reported that outcome.

\section{RESULTS}

\section{Results of the searches}

A total of 172 citations were retrieved from literature. Then, 163 were excluded when reading the titles and abstracts. Next, 16 full articles were obtained from literature. In addition, 7 articles were found by a manual search of cross-references. Of the 16 articles acquired from literature, 7 were excluded for the following reasons (no data on obstetric and perinatal outcomes $=5$; cryopreservation of $2 \mathrm{PN}$ oocyte were used in frozen-thawed BT $=2$ ). Nine retrospective/cohort/RCT studies were included in the completed review (Fig. 1). All retrospective/cohort studies scored high $(\geq 6)$ on the NOS checklists. Data were from the database.

\section{Characteristics of included studies}

Nine eligible studies with 42,342 participants that reported obstetric and perinatal outcomes of BT after frozen BT versus fresh BT (BT) cycles were incorporated in this review. Characteristics of each study are provided in Table 1. In the included studies, seven studies included patients undergoing IVF/ICSI [11-16], one study included couples undergoing only IVF [17], and one study included couples undergoing only ICSI [18]. Additionally, the vitrification technique was applied for blastocysts in seven studies, one study used vitrification or slow-freezing techniques [17], and the freezing technique was not mentioned in one study [19].

\section{Results of the outcome measures}

Preterm birth (delivery at $<37$ weeks) 
Nine studies ( $\mathrm{n}=30,891$ vs 11,451 pregnancies from frozen BT vs fresh BT) were included in the present study compared the preterm births after frozen BT versus fresh BT cycles. The RR of delivery at $<37$ weeks was $0.89(0.82-0.97)$ in singleton births after frozen BT compared with the risks after fresh BT (Fig. 2). Then, the Q statistic P-value $=0.007$, and the $\mathrm{I}^{2}=0 \%$. The results indicated that a significantly lower risk of preterm birth in singleton pregnancies resulted from frozen BT compared with those after fresh BT. The funnel plot did not show any publication bias (Fig. S1).

Extremely preterm birth (delivery at $<32$ weeks/ $<34$ weeks)

Five studies ( $n=29,581$ vs 9,957 pregnancies from frozen BT vs fresh BT) reported the proportion of deliveries at $<32$ weeks, and another two studies ( $n=569$ vs 586 pregnancies from frozen vs fresh BT) reported the proportion of deliveries at $<34$ weeks. Hence, we categorized two subgroups for our analysis: “deliveries at $<32$ weeks” and "deliveries at $<34$ weeks.” In the “deliveries at < 32 weeks” subgroup, the relative risk (95\% CI) was 1.05 (0.58-1.88) in singleton pregnancies after frozen BT as compared with those after fresh BT. The heterogeneity $\left(\mathrm{I}^{2}=58 \%\right)$ among the studies was high. In the "deliveries at $<34$ weeks" subgroup, the relative risk $(95 \% \mathrm{CI})$ was $1.07(0.53-2.16)$. There was no heterogeneity $\left(\mathrm{I}^{2}=\right.$ 0\%) among the studies (Fig. 3). Based on the above results, we concluded that extremely preterm birth was comparable between frozen BT and fresh BT. The funnel plot did not demonstrate any publication bias (Fig. S2).

Low birth weight (birth weight $<2,500 \mathrm{~g}$ )

Eight studies ( $\mathrm{n}=30,064$ vs 10,882 pregnancies from frozen BT vs fresh BT) included low birth weights defined as $<2,500 \mathrm{~g}$. The RR of birth weight $<2,500 \mathrm{~g}$ was 0.89 (0.67, 1.19) for frozen BT singletons compared with fresh BT newborns (Fig. 4). The Q statistic Pvalue $=0.43$, and the $\mathrm{I}^{2}=65 \%$, showing high heterogeneity. The results suggested that incidence of low birth weight in frozen BT is not higher than fresh BT group. No publication bias was found in the funnel plot (Fig. S3).

\section{Extremely low birth weight (birth weight $<1,500 \mathrm{~g}$ )}

In this meta-analysis, six studies $(\mathrm{n}=29,721$ vs 10,151 pregnancies after frozen BT vs fresh BT) examined extremely low birth weights. The RR of very low birth weight was 0.95 (0.50-1.80) for frozen BT singletons compared with fresh BT newborns. Furthermore, the Q statistic P-value $=0.86$, and the $\mathrm{I}^{2}=47 \%$. The results indicated that incidence of extremely 
low birth weight was comparable between frozen BT group and fresh BT group (Fig. 5). The funnel plot showed no publication bias (Fig. S4).

\section{Small for gestational age}

In our meta-analysis, four studies ( $\mathrm{n}=29,917$ vs 10,134 pregnancies after frozen BT vs fresh BT) investigated small for gestational age outcomes. Compared with singleton births of fresh BT, the RR of infants being small for gestational age with frozen BT was 0.55 (0.410.74) (Fig. 6). The Q statistic P-value $\square 0.001$, and the $\mathrm{I}^{2}=48 \%$. The results suggested that a significantly decreased risk of small for gestational age in singleton pregnancies resulted from frozen BT compared with that after fresh BT. The funnel plot did not show any publication bias (Fig. S5).

\section{Large for gestational age}

Four studies covered large for gestational age outcomes $(n=29,917$ vs 10,134 pregnancies after frozen BT vs fresh BT). The RR of infants being large for gestational age was 1.48 (1.38-1.58) in singleton births for frozen BT singletons compared with fresh BT newborns (Fig. 7), the statistic P-value was $<0.00001$, and there was low heterogeneity $\left(\mathrm{I}^{2}=\right.$ 7\%) among the studies. These results indicated that the incidence of large for gestational age in frozen BT group is higher than fresh BT group. The funnel plot did not demonstrate any publication bias (Fig. S6).

\section{Caesarean section}

Four studies were included in the meta-analysis ( $n=29,789$ vs 9,916 pregnancies after frozen BT vs fresh BT). Caesarean section in frozen BT group is higher than fresh BT group $\left(\mathrm{RR}=1.24,95 \%\right.$ CI 1.13-1.36) (Fig. 8), there was high heterogeneity $\left(\mathrm{I}^{2}=55 \%\right)$ among these studies. No publication bias was found in the funnel plot (Fig. S7).

\section{Perinatal mortality}

Of the three studies ( $n=2,125$ vs 3,732 pregnancies after frozen BT vs fresh BT) that reported perinatal mortality, the RR of perinatal mortality was 1.47 (95\% CI 0.85-2.55) in singleton pregnancies for frozen BT versus fresh BTs (Fig. 9). There was no heterogeneity ( $\mathrm{I}^{2}$ $=0 \%$ ) among the studies. The results suggested that there was no increased risk of perinatal mortality after frozen BT compared with the risk after fresh BT. The funnel plot did not reveal any publication bias (Fig. S8). 


\section{Preeclampsia}

There were four studies indicated preeclampsia in the meta-analysis ( $n=2,569$ vs 4,205 pregnancies after frozen BT vs fresh BT). Preeclampsia incidence of frozen BT group is higher than fresh BT group (RR = 1.85, 95\% CI 1.22-2.82) (Fig. 10). No publication bias was found in the funnel plot (Fig. S9).

\section{DISCUSSION}

This meta-analysis compares the obstetric and perinatal outcomes of singleton pregnancies between frozen BT and fresh BTs for the first time. In this meta-analysis, we found the risks of both preterm births and infants being small for gestational age were lower after frozen BT than after fresh BTs. In addition, the rate of large for gestational age and caesarean section in pregnancies of frozen BT group was higher than that of fresh BT group.

The possible explanations of lower rates of preterm birth and small for gestational age but higher rate of large for gestational age in frozen BT group are as follows: First, the supraphysiological hormonal conditions produced by controlled ovarian stimulation (COS) certainly have the potential to adversely affect many aspects of early conception [20, 21]. In addition, frozen BT allows for the removal of iatrogenically administered gonadotropins and recovery of the stimulated ovaries. Compared with fresh BT, the frozen BT was in a more favourable endometrial environment, which may have a positive effect, such as better endometrial receptivity, more suitable for placentation and subsequent fetal growth [22, 23]. Second, some studies have shown that large for gestational age in frozen BT may be due to epigenetic alterations at the early embryonic stages during freezing/thawing [24, 25]. Third, genomewide miRNA analysis suggested that the expression of several miRNAs in placentae of the frozen embryo group are involved in an increase of a higher incidence of large for gestational age [26].

In addition, we found that the perinatal mortality incidence of frozen BT group is similar to fresh BT group. The rate of caesarean section and preeclampsia in frozen BT group was higher than that of fresh BT group. The possible reasons may be as follows: first, for those women undergoing frozen BT, they were more likely to have had previous caesarean sections than women undergoing fresh BT. Second, pregnant women after frozen BT may have tried many times before the final pregnancy, and they preferred to choose caesarean section to deliver quickly and safely [8, 27]. Thirdly, It is possible that the vitrification and warming process may affect the developing trophoblast and account for the increased rate of preeclampsia [28]. Finally, one recent study found that vitrified-warmed single BT may be 
associated with an increased risk of maternal complications such as preeclampsia and gestational diabetes mellitus (GDM), as well as neonatal complications such as large for gestational age; thus, the elevated risk may be attributed to the higher rates of preeclampsia, GDM and large for gestational age, which are known risk factors for caesarean deliveries [29, 30].

However, we found no significant difference of low birth weight between the two groups. But many other studies have found significant differences in the birth weights between singleton frozen BT pregnancies and fresh BT $[17,19]$. The possible reason is that serum $\mathrm{E}_{2}$ may be an independent predictor of term LBW and VLBW in normal responders undergoing fresh IVF-ET cycles, and it was amplified in high responders [31, 32]. Therefore, the predictive ability of $E_{2}$ for term LBW needs prospective validation and calibration in an independent sample of similar patients.

Because there is only one randomized controlled trial, the rest of studies included in this review are observational studies. Therefore, our meta-analysis has some important limitations that are common in this type of study: 1) There were many differences among observational studies, such as design, exclusion and inclusion criteria, definition of results, methodology; 2) population in fresh cycles are made up of both good and bad prognosis patients, while patients in the frozen cycle are more with better prognosis, hence there might be difference in the outcomes; 3) due to lack of original individual-level data, it is impossible for us to adjust for some confounders and determine whether there were difference in risks between embryos frozen by slow freezing and vitrification; 4) not all outcomes have been reported by all studies; 5) definitions for some outcomes also differed among different studies, such as very preterm birth.

In conclusion, the frozen BT results in better perinatal outcomes compared with that of fresh BT. Thus, all available blastocysts can be frozen in patients for whom fresh BT is unsuitable, such as patients at risk of OHSS, those with a history of repeated attempts and failed fresh embryo transfers, and those in need of pre-implantation genomic diagnosis. Furthermore, comprehensive randomized clinical trials comparing freeze-all with fresh BT cycles are needed to draw sound conclusions. In addition, follow-up investigations on infant growth and developmental progress need to be updated.

\section{Acknowledgements}

This work was supported by grants from National Key Research and Development Plan (2016YFC1000600); Municipal Health and Family Planning Commission research 
project (2016). We acknowledge the professional language editing services of Springer Nature Author Services.

\section{XREFERENCES}

1. de Mouzon J, Goossens V, Bhattacharya S, et al. Assisted reproductive technology in Europe, 2006: results generated from European registers by ESHRE. Human Reproduction. 2010; 25(8): 1851-1862, doi: 10.1093/humrep/deq124, indexed in Pubmed: 20570973.

2. Devroey P, Polyzos NP, Blockeel C. An OHSS-Free Clinic by segmentation of IVF treatment. Hum Reprod. 2011; 26(10): 2593-2597, doi: 10.1093/humrep/der251, indexed in Pubmed: 21828116.

3. Roque M, Lattes K, Serra S, et al. Fresh embryo transfer versus frozen embryo transfer in in vitro fertilization cycles: a systematic review and meta-analysis. Fertil Steril. 2013; 99(1): 156-162, doi: 10.1016/j.fertnstert.2012.09.003, indexed in Pubmed: 23040524.

4. Wong KM, van Wely M, Mol F, et al. Fresh versus frozen embryo transfers in assisted reproduction. Cochrane Database Syst Rev. 2017; 3: CD011184, doi: 10.1002/14651858.CD011184.pub2, indexed in Pubmed: 28349510.

5. Practice Committee of the American Society for Reproductive Medicine. Electronic address: ASRM@asrm.org, Practice Committee of the Society for Assisted Reproductive Technology. Guidance on the limits to the number of embryos to transfer: a committee opinion. Fertil Steril. 2017; 107(4): 901-903, doi: 10.1016/j.fertnstert.2017.02.107, indexed in Pubmed: 28292618.

6. Blake DA, Farquhar CM, Johnson N, et al. Cleavage stage versus blastocyst stage embryo transfer in assisted conception. Cochrane Database Syst Rev. 2007(4): CD002118, doi: 10.1002/14651858.CD002118.pub3, indexed in Pubmed: 17943767.

7. Henman M, Catt JW, Wood T, et al. Elective transfer of single fresh blastocysts and later transfer of cryostored blastocysts reduces the twin pregnancy rate and can improve the in vitro fertilization live birth rate in younger women. Fertil Steril. 2005; 
84(6): 1620-1627, doi: 10.1016/j.fertnstert.2005.05.064, indexed in Pubmed: 16359955.

8. Maheshwari A, Pandey S, Shetty A, et al. Obstetric and perinatal outcomes in singleton pregnancies resulting from the transfer of frozen thawed versus fresh embryos generated through in vitro fertilization treatment: a systematic review and meta-analysis. Fertil Steril. 2012; 98(2): 368-77.e1, doi:

10.1016/j.fertnstert.2012.05.019, indexed in Pubmed: 22698643.

9. Alviggi C, Conforti A, Carbone IF, et al. Influence of cryopreservation on perinatal outcome after blastocyst- vs cleavage-stage embryo transfer: systematic review and meta-analysis. Ultrasound Obstet Gynecol. 2018; 51(1): 54-63, doi:

10.1002/uog.18942, indexed in Pubmed: 29077229.

10. Wei D, Liu JY, Sun Y, et al. Frozen versus fresh single blastocyst transfer in ovulatory women: a multicentre, randomised controlled trial. The Lancet. 2019; 393(10178): 1310-1318, doi: 10.1016/s0140-6736(18)32843-5, indexed in Pubmed: 30827784.

11. Wikland M, Hardarson T, Hillensjö T, et al. Obstetric outcomes after transfer of vitrified blastocysts. Hum Reprod. 2010; 25(7): 1699-1707, doi: 10.1093/humrep/deq117, indexed in Pubmed: 20472913.

12. Feng G, Zhang Bo, Zhou H, et al. Comparable clinical outcomes and live births after single vitrified-warmed and fresh blastocyst transfer. Reprod Biomed Online. 2012; 25(5): 466-473, doi: 10.1016/j.rbmo.2012.07.008, indexed in Pubmed: 22995746.

13. Ishihara O, Araki R, Kuwahara A, et al. Impact of frozen-thawed single-blastocyst transfer on maternal and neonatal outcome: an analysis of 277,042 single-embryo transfer cycles from 2008 to 2010 in Japan. Fertil Steril. 2014; 101(1): 128-133, doi:

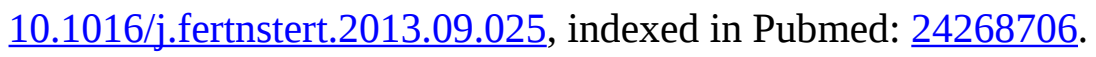

14. Roy TK, Bradley CK, Bowman MC, et al. Single-embryo transfer of vitrified-warmed blastocysts yields equivalent live-birth rates and improved neonatal outcomes compared with fresh transfers. Fertil Steril. 2014; 101(5): 1294-1301, doi: $\underline{\text { 10.1016/j.fertnstert.2014.01.046, indexed in Pubmed: } 24582521 .}$ 
15. Pereira N, Petrini AC, Lekovich JP, et al. Comparison of perinatal outcomes following fresh and frozen-thawed blastocyst transfer. Int J Gynaecol Obstet. 2016; 135(1): 96100, doi: 10.1016/j.ijgo.2016.04.007, indexed in Pubmed: 27388034.

16. Shavit T, Oron G, Weon-Young S, et al. Vitrified-warmed single-embryo transfers may be associated with increased maternal complications compared with fresh singleembryo transfers. Reprod Biomed Online. 2017; 35(1): 94-102, doi: 10.1016/j.rbmo.2017.03.016, indexed in Pubmed: 28427857.

17. Ginström Ernstad E, Bergh C, Khatibi A, et al. Neonatal and maternal outcome after blastocyst transfer: a population-based registry study. Am J Obstet Gynecol. 2016; 214(3): 378.e1-378.e10, doi: 10.1016/j.ajog.2015.12.040, indexed in Pubmed: 26928152.

18. Ozgur K, Berkkanoglu M, Bulut $\mathrm{H}$, et al. Perinatal outcomes after fresh versus vitrified-warmed blastocyst transfer: retrospective analysis. Fertil Steril. 2015; 104(4): 899-907.e3, doi: 10.1016/j.fertnstert.2015.06.031, indexed in Pubmed: 26211882.

19. Ishihara O, Araki R, Kuwahara A, et al. Impact of frozen-thawed single-blastocyst transfer on maternal and neonatal outcome: an analysis of 277,042 single-embryo transfer cycles from 2008 to 2010 in Japan. Fertil Steril. 2014; 101(1): 128-133, doi: 10.1016/j.fertnstert.2013.09.025, indexed in Pubmed: 24268706.

20. Sha T, Yin X, Cheng W, et al. Pregnancy-related complications and perinatal outcomes resulting from transfer of cryopreserved versus fresh embryos in vitro fertilization: a meta-analysis. Fertil Steril. 2018; 109(2): 330-342.e9, doi: 10.1016/j.fertnstert.2017.10.019, indexed in Pubmed: 29331236.

21. Pereira N, Elias RT, Christos PJ, et al. Supraphysiologic estradiol is an independent predictor of low birth weight in full-term singletons born after fresh embryo transfer. Hum Reprod. 2017; 32(7): 1410-1417, doi: 10.1093/humrep/dex095, indexed in Pubmed: $\underline{28505290}$.

22. Ming Li, Liu P, Qiao J, et al. Synchronization between embryo development and endometrium is a contributing factor for rescue ICSI outcome. Reprod Biomed 
Online. 2012; 24(5): 527-531, doi: 10.1016/j.rbmo.2012.02.001, indexed in Pubmed: $\underline{22480904 .}$.

23. Luke B, Brown MB, Wantman E, et al. Increased risk of large-for-gestational age birthweight in singleton siblings conceived with in vitro fertilization in frozen versus fresh cycles. J Assist Reprod Genet. 2017; 34(2): 191-200, doi: 10.1007/s10815-0160850-X, indexed in Pubmed: 27909843.

24. Pinborg A, Henningsen AA, Loft A, et al. Large baby syndrome in singletons born after frozen embryo transfer (FET): is it due to maternal factors or the cryotechnique? Hum Reprod. 2014; 29(3): 618-627, doi: 10.1093/humrep/det440, indexed in Pubmed: 24413766.

25. Berntsen S, Pinborg A. Large for gestational age and macrosomia in singletons born after frozen/thawed embryo transfer (FET) in assisted reproductive technology (ART). Birth Defects Res. 2018; 110(8): 630-643, doi: 10.1002/bdr2.1219, indexed in Pubmed: 29714057.

26. Hiura H, Hattori H, Kobayashi N, et al. Genome-wide microRNA expression profiling in placentae from frozen-thawed blastocyst transfer. Clin Epigenetics. 2017; 9: 79, doi: 10.1186/s13148-017-0379-6, indexed in Pubmed: 28785370.

27. Zhao J, Xu B, Zhang Q, et al. Which one has a better obstetric and perinatal outcome in singleton pregnancy, IVF/ICSI or FET?: a systematic review and meta-analysis. Reprod Biol Endocrinol. 2016; 14(1): 51, doi: 10.1186/s12958-016-0188-3, indexed in Pubmed: 27577996.

28. Barsky M, St Marie P, Rahil T, et al. Are perinatal outcomes affected by blastocyst vitrification and warming? Am J Obstet Gynecol. 2016; 215(5): 603.e1-603.e5, doi: 10.1016/j.ajog.2016.06.002, indexed in Pubmed: 27287684.

29. Liu SY, Teng B, Fu J, et al. Obstetric and neonatal outcomes after transfer of vitrified early cleavage embryos. Hum Reprod. 2013; 28(8): 2093-2100, doi: 10.1093/humrep/det104, indexed in Pubmed: 23569081. 
30. Wennerholm UB, Henningsen AKA, Romundstad LB, et al. Perinatal outcomes of children born after frozen-thawed embryo transfer: a Nordic cohort study from the CoNARTaS group. Hum Reprod. 2013; 28(9): 2545-2553, doi:

10.1093/humrep/det272, indexed in Pubmed: 23832793.

31. Pereira N, Elias RT, Christos PJ, et al. Supraphysiologic estradiol is an independent predictor of low birth weight in full-term singletons born after fresh embryo transfer. Hum Reprod. 2017; 32(7): 1410-1417, doi: 10.1093/humrep/dex095, indexed in Pubmed: $\underline{28505290}$.

32. Kalem Z, Namli Kalem M, Ruso H, et al. Fresh versus frozen-thawed blastocyst transfer in high responders. Ginekol Pol. 2018; 89(8): 407-413, doi:

10.5603/GP.a2018.0070, indexed in Pubmed: $\underline{30215458}$.

Table 1. Characteristics of studies included in the meta-analysis

\begin{tabular}{|c|c|c|c|c|c|c|c|c|}
\hline Study & $\begin{array}{l}\text { Area/dur } \\
\text { ation }\end{array}$ & $\begin{array}{l}\text { Study } \\
\text { type }\end{array}$ & $\begin{array}{l}\text { Popula } \\
\text { tion }\end{array}$ & $\begin{array}{l}\text { Freezing } \\
\text { techniques }\end{array}$ & $\begin{array}{l}\text { Method of } \\
\text { data } \\
\text { collection }\end{array}$ & $\begin{array}{l}\text { Risk } \\
\text { of bias }\end{array}$ & Outcomes & NOS \\
\hline $\begin{array}{l}\text { M. } \\
\text { Wikland } \\
2010\end{array}$ & $\begin{array}{l}\text { Sweden } \\
2006- \\
2008\end{array}$ & $\begin{array}{l}\text { Retrospe } \\
\text { ctive } \\
\text { cohort } \\
\text { study }\end{array}$ & $\begin{array}{l}\text { IVF/IC } \\
\text { SI vs } \\
\text { FET }\end{array}$ & $\begin{array}{l}\text { Vitrificatio } \\
\mathrm{n}\end{array}$ & $\begin{array}{l}\text { In their } \\
\text { computeriz } \\
\text { ed } \\
\text { database }\end{array}$ & $\begin{array}{l}\text { The } \\
\text { charac } \\
\text { teristic } \\
\text { s of } \\
\text { two } \\
\text { groups } \\
\text { are } \\
\text { similar } \\
\text {. All } \\
\text { pregna } \\
\text { ncies } \\
\text { were } \\
\text { includ } \\
\text { ed }\end{array}$ & $\begin{array}{l}\text { Preterm birth; } \\
\text { very preterm } \\
\text { birth; LBW; } \\
\text { VLBW; SGA, } \\
\text { LGA; } \\
\text { Perinatial } \\
\text { mortality; } \\
\text { Cesarean } \\
\text { section; } \\
\text { Preeclampsia }\end{array}$ & 8 \\
\hline $\begin{array}{l}\text { Guixue } \\
\text { Feng } 2012\end{array}$ & $\begin{array}{l}\text { China } \\
2009- \\
2010\end{array}$ & $\begin{array}{l}\text { Cohort } \\
\text { study }\end{array}$ & $\begin{array}{l}\text { IVF/IC } \\
\text { SI vs } \\
\text { FET }\end{array}$ & $\begin{array}{l}\text { Vitrificatio } \\
\mathrm{n}\end{array}$ & $\begin{array}{l}\text { In their } \\
\text { computeriz } \\
\text { ed } \\
\text { database }\end{array}$ & $\begin{array}{l}\text { The } \\
\text { charac } \\
\text { teristic } \\
\text { s of }\end{array}$ & $\begin{array}{l}\text { Preterm birth; } \\
\text { very preterm } \\
\text { birth; LBW; } \\
\text { VLBW }\end{array}$ & 8 \\
\hline
\end{tabular}




\begin{tabular}{|c|c|c|c|c|c|c|c|c|}
\hline & & & & & & $\begin{array}{l}\text { two } \\
\text { groups } \\
\text { are } \\
\text { similar } \\
\text {. All } \\
\text { pregna } \\
\text { ncies } \\
\text { were } \\
\text { includ } \\
\text { ed }\end{array}$ & & \\
\hline $\begin{array}{l}\text { Osamu } \\
\text { Ishihara } \\
2014\end{array}$ & $\begin{array}{l}\text { Japan } \\
2008- \\
2010\end{array}$ & $\begin{array}{l}\text { Retrospe } \\
\text { ctive } \\
\text { study }\end{array}$ & $\begin{array}{l}\text { IVF/IC } \\
\text { SI vs } \\
\text { FET }\end{array}$ & $\begin{array}{l}\text { Not } \\
\text { vitrification }\end{array}$ & $\begin{array}{l}\text { Japanese } \\
\text { ART } \\
\text { registry } \\
\text { data base }\end{array}$ & $\begin{array}{l}\text { Thenu } \\
\text { mber } \\
\text { of } \\
\text { fresh } \\
\text { blastoc } \\
\text { yst } \\
\text { transfe } \\
\text { r is } \\
\text { very } \\
\text { low } \\
\text { relativ } \\
\text { e to } \\
\text { the } \\
\text { numer } \\
\text { of } \\
\text { frozen } \\
\text { blastoc } \\
\text { yst } \\
\text { transfe } \\
\text { rs }\end{array}$ & $\begin{array}{l}\text { Preterm birth; } \\
\text { very preterm } \\
\text { birth; LBW; } \\
\text { VLBW; SGA, } \\
\text { LGA; } \\
\text { Cesarean } \\
\text { section }\end{array}$ & 7 \\
\hline $\begin{array}{l}\text { Tammie } \\
\text { K. Roy } \\
2014\end{array}$ & $\begin{array}{l}\text { Australia } \\
2010- \\
2011\end{array}$ & $\begin{array}{l}\text { Retrospe } \\
\text { ctive } \\
\text { study }\end{array}$ & $\begin{array}{l}\text { IVF/IC } \\
\text { SI vs } \\
\text { FET }\end{array}$ & $\begin{array}{l}\text { Vitrificatio } \\
\mathrm{n}\end{array}$ & $\begin{array}{l}\text { In their } \\
\text { computeriz } \\
\text { ed } \\
\text { database }\end{array}$ & $\begin{array}{l}\text { PGD } \\
\text { and } \\
\text { donor- } \\
\text { recipie } \\
\text { nt and } \\
\text { surrog } \\
\text { acy } \\
\text { cases } \\
\text { were } \\
\text { includ } \\
\text { ed }\end{array}$ & $\begin{array}{l}\text { Preterm birth; } \\
\text { LBW; } \\
\text { Perinatal } \\
\text { mortality }\end{array}$ & 8 \\
\hline $\begin{array}{l}\text { Kemal } \\
\text { Ozgur } \\
2015\end{array}$ & $\begin{array}{l}\text { Denmark } \\
2012- \\
2013\end{array}$ & $\begin{array}{l}\text { Retrospe } \\
\text { ctive } \\
\text { study }\end{array}$ & $\begin{array}{l}\text { ICSI vs } \\
\text { FET }\end{array}$ & $\begin{array}{l}\text { Vitrificatio } \\
\mathrm{n}\end{array}$ & $\begin{array}{l}\text { In their } \\
\text { computeriz } \\
\text { ed } \\
\text { database }\end{array}$ & $\begin{array}{l}\text { Only } \\
\text { double } \\
\text { blastoc } \\
\text { yst } \\
\text { transfe } \\
\text { r were } \\
\text { includ } \\
\text { ed }\end{array}$ & $\begin{array}{l}\text { Preterm birth; } \\
\text { very preterm } \\
\text { birth; LBW; } \\
\text { VLBW }\end{array}$ & 8 \\
\hline Nigel & United & Retrospe & IVF/IC & Vitrificatio & In their & The & Preterm birth; & 9 \\
\hline
\end{tabular}




\begin{tabular}{|c|c|c|c|c|c|c|c|c|}
\hline $\begin{array}{l}\text { Pereira } \\
2016\end{array}$ & $\begin{array}{l}\text { States } \\
2010- \\
2013\end{array}$ & $\begin{array}{l}\text { ctive } \\
\text { cohort } \\
\text { study }\end{array}$ & $\begin{array}{l}\text { SI vs } \\
\text { FET }\end{array}$ & $\mathrm{n}$ & $\begin{array}{l}\text { computeriz } \\
\text { ed } \\
\text { database }\end{array}$ & $\begin{array}{l}\text { charac } \\
\text { teristic } \\
\text { s of } \\
\text { two } \\
\text { groups } \\
\text { are } \\
\text { similar } \\
\text {. All } \\
\text { pregna } \\
\text { ncies } \\
\text { are } \\
\text { includ } \\
\text { ed }\end{array}$ & $\begin{array}{l}\text { very preterm } \\
\text { birth; LBW; } \\
\text { Cesarean } \\
\text { section }\end{array}$ & \\
\hline $\begin{array}{l}\text { Erica } \\
\text { Ginstrom } \\
\text { Emstad } \\
2016\end{array}$ & $\begin{array}{l}\text { Sweden } \\
2002- \\
2013\end{array}$ & $\begin{array}{l}\text { Retrospe } \\
\text { ctive } \\
\text { study }\end{array}$ & $\begin{array}{l}\text { ICSI vs } \\
\text { FET }\end{array}$ & $\begin{array}{l}\text { Vitrificatio } \\
\text { n/slow- } \\
\text { freezing }\end{array}$ & $\begin{array}{l}\text { Swedish } \\
\text { Medical } \\
\text { Birth } \\
\text { Register } \\
\text { and the } \\
\text { National } \\
\text { Patient } \\
\text { Register }\end{array}$ & $\begin{array}{l}\text { No } \\
\text { ICSI } \\
\text { cycles } \\
\text { in the } \\
\text { study }\end{array}$ & $\begin{array}{l}\text { Preterm birth; } \\
\text { very preterm } \\
\text { birth; LBW; } \\
\text { VLBW; SGA, } \\
\text { LGA; } \\
\text { Perinatial } \\
\text { mortality; } \\
\text { Cesarean } \\
\text { section; } \\
\text { Preeclampsia } \\
\end{array}$ & 8 \\
\hline $\begin{array}{l}\text { Tal Shavit } \\
2017\end{array}$ & $\begin{array}{l}\text { Canada } \\
2008- \\
2012\end{array}$ & $\begin{array}{l}\text { Retrospe } \\
\text { ctive } \\
\text { cohort } \\
\text { study }\end{array}$ & $\begin{array}{l}\text { IVF/IC } \\
\text { SI vs } \\
\text { FET }\end{array}$ & $\begin{array}{l}\text { Vitrificatio } \\
\mathrm{n}\end{array}$ & $\begin{array}{l}\text { In their } \\
\text { computeriz } \\
\text { ed } \\
\text { database }\end{array}$ & $\begin{array}{l}\text { Some } \\
\text { patient } \\
\text { s do } \\
\text { not } \\
\text { have } \\
\text { compl } \\
\text { ete } \\
\text { inform } \\
\text { ation } \\
\end{array}$ & $\begin{array}{l}\text { Preterm birth; } \\
\text { very preterm } \\
\text { birth; LBW; } \\
\text { VLBW; SGA, } \\
\text { LGA; } \\
\text { Cesarean } \\
\text { section; } \\
\text { Preeclampsia }\end{array}$ & 8 \\
\hline $\begin{array}{l}\text { Daimin } \\
\text { Wei } 2019\end{array}$ & $\begin{array}{l}\text { China } \\
2016- \\
2017\end{array}$ & $\begin{array}{l}\text { Random } \\
\text { ized } \\
\text { controlle } \\
\mathrm{d} \text { trial } \\
\end{array}$ & $\begin{array}{l}\text { IVF/IC } \\
\text { SI vs } \\
\text { FET }\end{array}$ & $\begin{array}{l}\text { Vitrificatio } \\
\mathrm{n}\end{array}$ & - & - & $\begin{array}{l}\text { Preterm birth; } \\
\text { SGA; LGA; } \\
\text { Preeclampsia }\end{array}$ & - \\
\hline
\end{tabular}

Figure 1. Selection of studies included in the review 


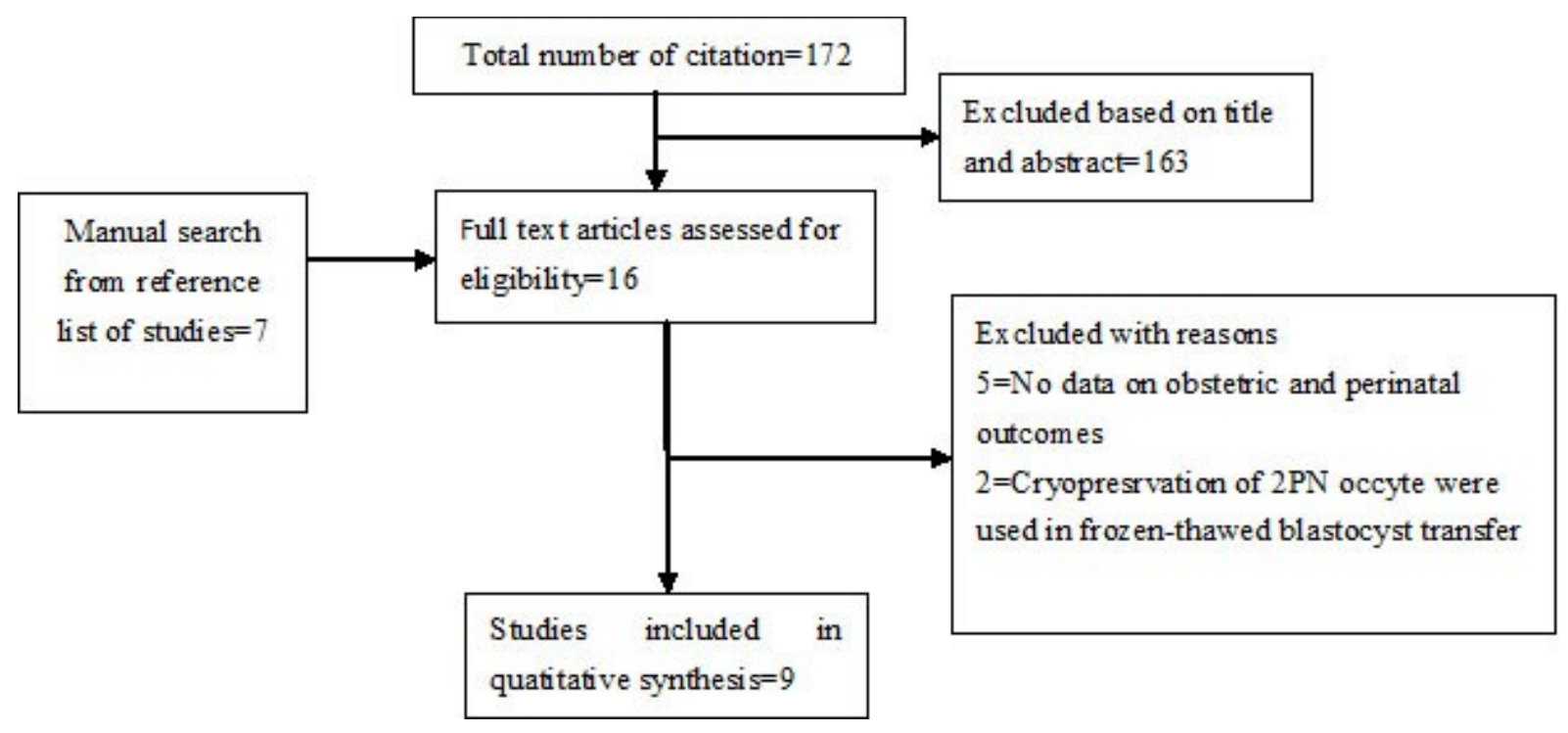

Figure 2. Comparison of frozen BT vs fresh BT on preterm birth

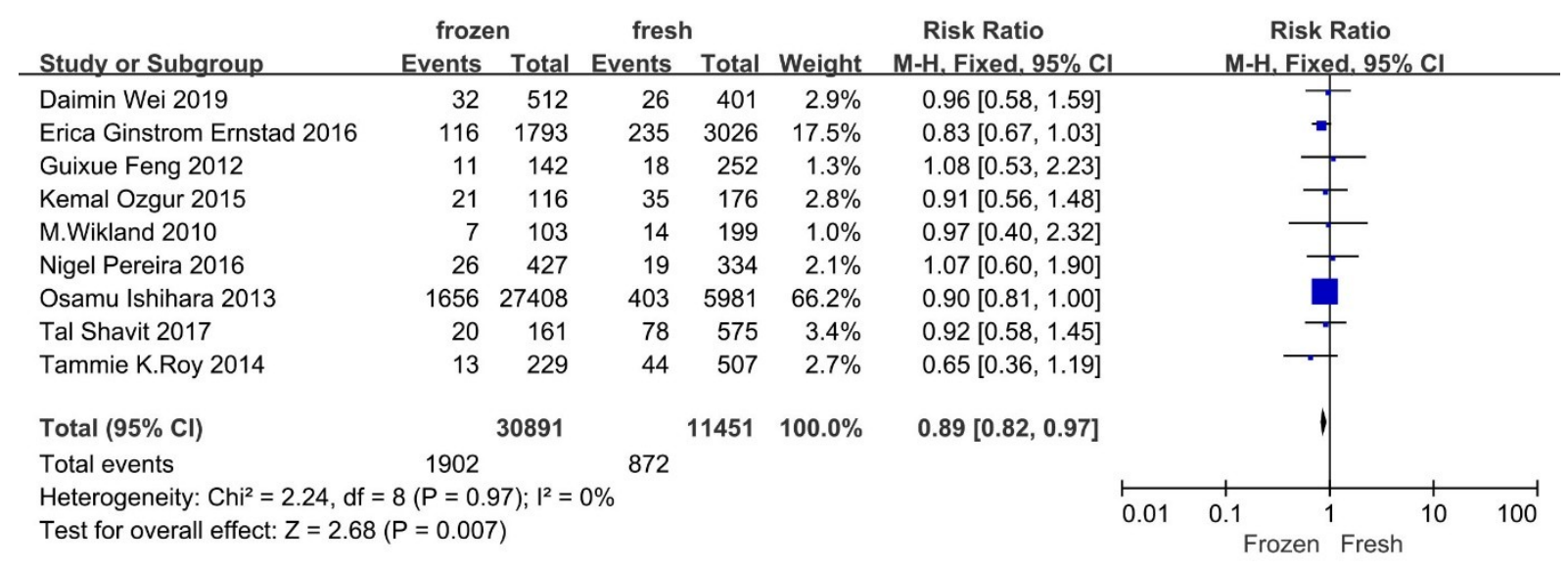

Figure 3. Comparison of frozen BT vs fresh BT on very preterm birth 


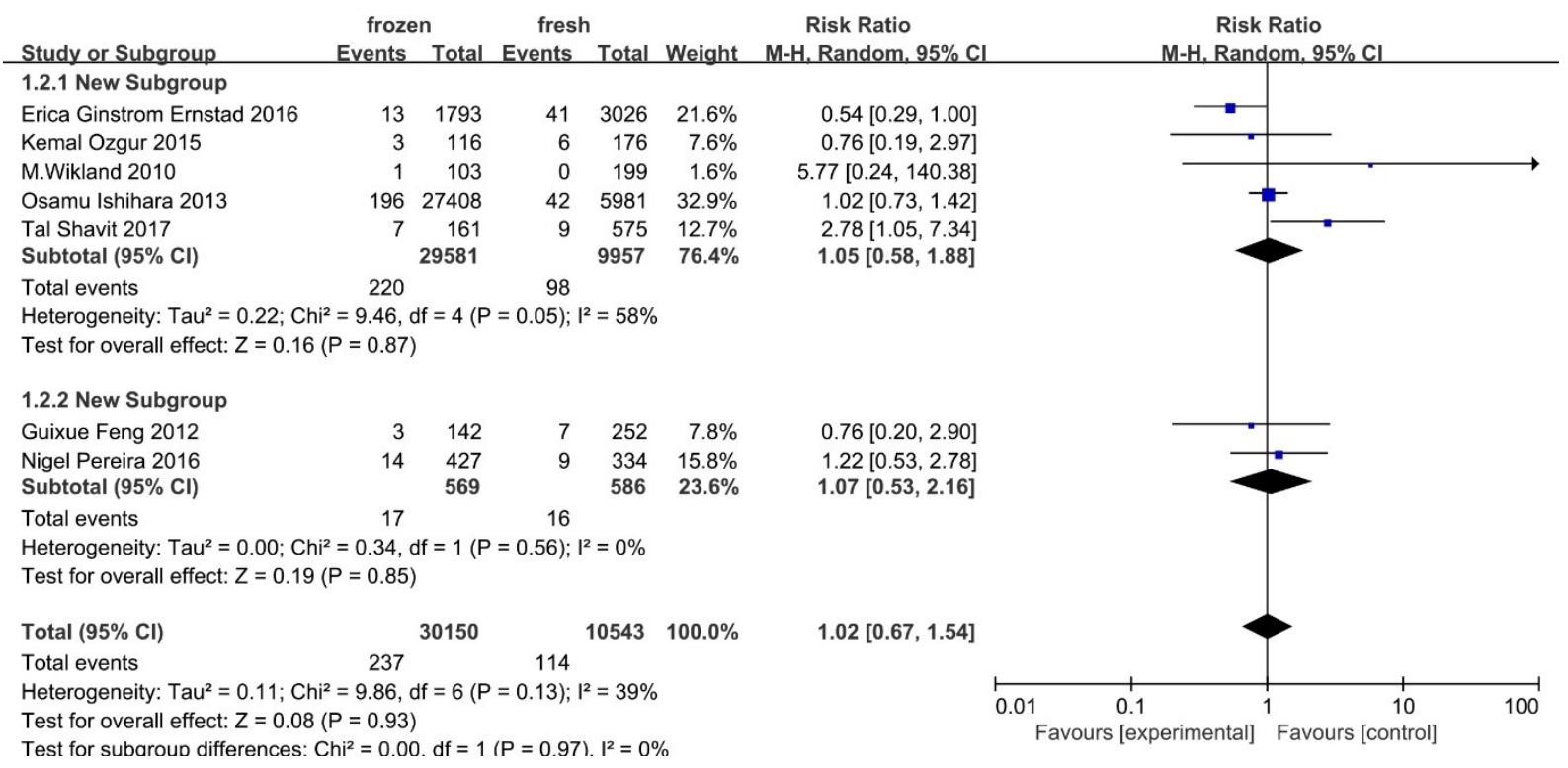

Figure 4. Comparison of frozen BT vs fresh BT on low birth weight

\begin{tabular}{|c|c|c|c|c|c|c|c|c|c|c|c|}
\hline \multirow{3}{*}{$\begin{array}{l}\text { Study or Subgroup } \\
\text { Erica Ginstrom Ernstad } 2016\end{array}$} & \multirow{2}{*}{$\begin{array}{l}\text { froze } \\
\text { Events }\end{array}$} & \multirow{2}{*}{ Total } & \multicolumn{2}{|c|}{ fresh } & \multirow[b]{2}{*}{ Weight } & \multirow{2}{*}{$\begin{array}{c}\text { Risk Ratio } \\
\mathrm{M}-\mathrm{H} \text {. Random. } 95 \% \mathrm{Cl}\end{array}$} & & \multirow{2}{*}{\multicolumn{3}{|c|}{$\begin{array}{c}\text { Risk Ratio } \\
\mathrm{M}-\mathrm{H}, \text { Random, } 95 \% \mathrm{Cl} \\
\end{array}$}} & \\
\hline & & & Events & Total & & & & & & & \\
\hline & 46 & 1793 & 146 & 3026 & $19.0 \%$ & $0.53[0.38,0.74]$ & & & - & & \\
\hline Guixue Feng 2012 & 8 & 142 & 20 & 252 & $8.7 \%$ & $0.71[0.32,1.57]$ & & & & & \\
\hline Kemal Ozgur 2015 & 8 & 114 & 12 & 171 & $7.8 \%$ & $1.00[0.42,2.37]$ & & & & & \\
\hline M.Wikland 2010 & 7 & 103 & 9 & 199 & $6.7 \%$ & $1.50[0.58,3.92]$ & & & & 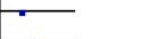 & \\
\hline Nigel Pereira 2016 & 15 & 114 & 12 & 171 & $9.8 \%$ & $1.88[0.91,3.86]$ & & & & & \\
\hline Osamu Ishihara 2013 & 2468 & 27408 & 758 & 5981 & $24.6 \%$ & $0.71[0.66,0.77]$ & & & - & & \\
\hline Tal Shavit 2017 & 17 & 161 & 41 & 575 & $13.4 \%$ & $1.48[0.86,2.54]$ & & & & $=$ & \\
\hline Tammie K.Roy 2014 & 10 & 229 & 28 & 507 & $10.1 \%$ & $0.79[0.39,1.60]$ & & & & & \\
\hline Total $(95 \% \mathrm{Cl})$ & & 30064 & & 10882 & $100.0 \%$ & $0.89[0.67,1.19]$ & & & & & \\
\hline Total events & 2579 & & 1026 & & & & & & & & \\
\hline $\begin{array}{l}\text { Heterogeneity: } \mathrm{Tau}^{2}=0.09 ; C \\
\text { Test for overall effect: } Z=0.78\end{array}$ & $\begin{array}{l}=19.99 \\
P=0.43)\end{array}$ & $d f=7($ & $=0.006$ & $; I^{2}=6$ & & & 0.01 & 0.1 & frozen ${ }^{1}$ & fresh & 100 \\
\hline
\end{tabular}

Figure 5. Comparison of frozen BT vs fresh BT on very low birth weight

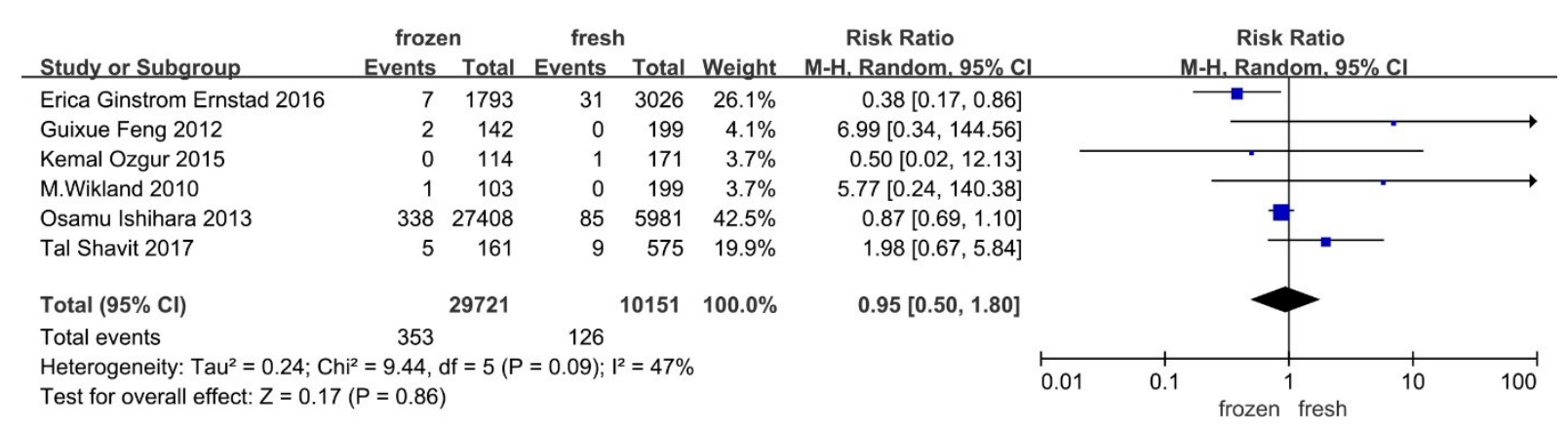

Figure 6. Comparison of frozen BT vs fresh BT on small for gestational age 


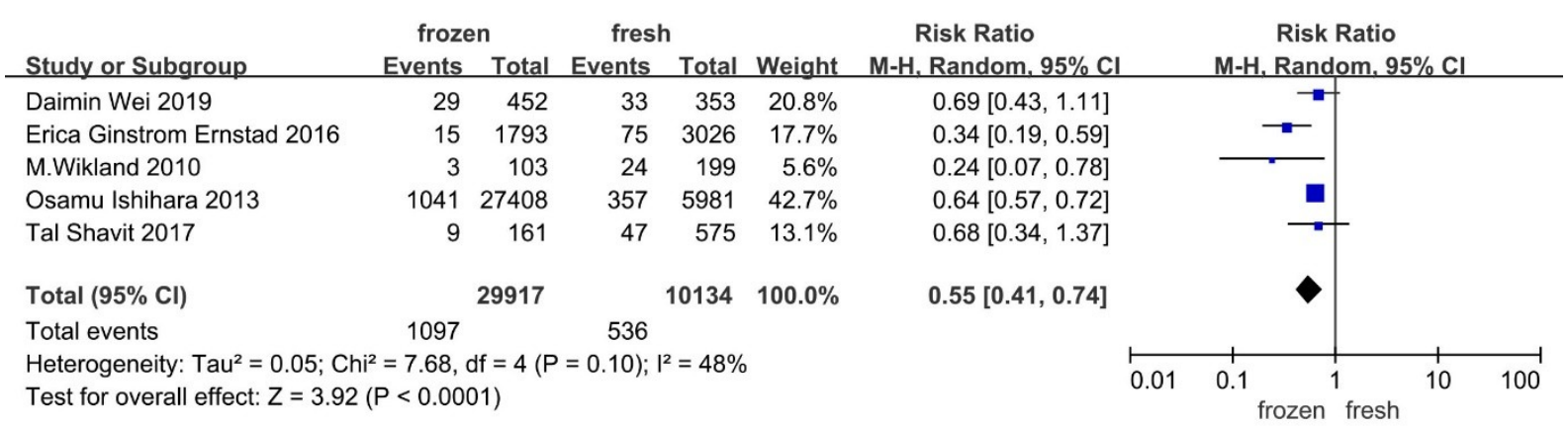

Figure 7. Comparison of frozen BT vs fresh BT on large for gestational age

\begin{tabular}{|c|c|c|c|c|c|c|c|c|c|c|}
\hline Study or Subgroup & \multicolumn{2}{|c|}{ frozen } & \multicolumn{2}{|c|}{ fresh } & Weight & $\begin{array}{c}\text { Risk Ratio } \\
\text { M-H. Fixed. } 95 \% \mathrm{Cl}\end{array}$ & \multicolumn{4}{|c|}{$\begin{array}{c}\text { Risk Ratio } \\
\text { M-H. Fixed, } 95 \% \mathrm{Cl}\end{array}$} \\
\hline Daimin Wei 2019 & 84 & 452 & 41 & 353 & $3.3 \%$ & $1.60[1.13,2.26]$ & & & - & \\
\hline Erica Ginstrom Ernstad 2016 & 7 & 103 & 14 & 199 & $0.7 \%$ & $0.97[0.40,2.32]$ & & & — & \\
\hline M.Wikland 2010 & 4989 & 27408 & 741 & 5981 & $87.2 \%$ & $1.47[1.37,1.58]$ & & & & \\
\hline Osamu Ishihara 2013 & 105 & 1793 & 128 & 3026 & $6.8 \%$ & $1.38[1.08,1.78]$ & & & $\mp$ & \\
\hline Tal Shavit 2017 & 36 & 161 & 63 & 575 & $2.0 \%$ & $2.04[1.41,2.96]$ & & & $\rightarrow$ & \\
\hline Total $(95 \% \mathrm{Cl})$ & & 29917 & & 10134 & $100.0 \%$ & $1.48[1.38,1.58]$ & & & 1 & \\
\hline Total events & 5221 & & 987 & & & & & & & \\
\hline $\begin{array}{l}\text { Heterogeneity: } \mathrm{Chi}^{2}=4.32, \mathrm{df} \\
\text { Test for overall effect: } Z=11 .\end{array}$ & $\begin{array}{l}4(P=0.3 \\
(P<0.00\end{array}$ & $\begin{array}{l}36) ; 1^{2}= \\
0001)\end{array}$ & $7 \%$ & & & & 0.01 & 0.1 & 1 fresh & 100 \\
\hline
\end{tabular}

Figure 8. Comparison of frozen BT vs fresh BT on caesarean section

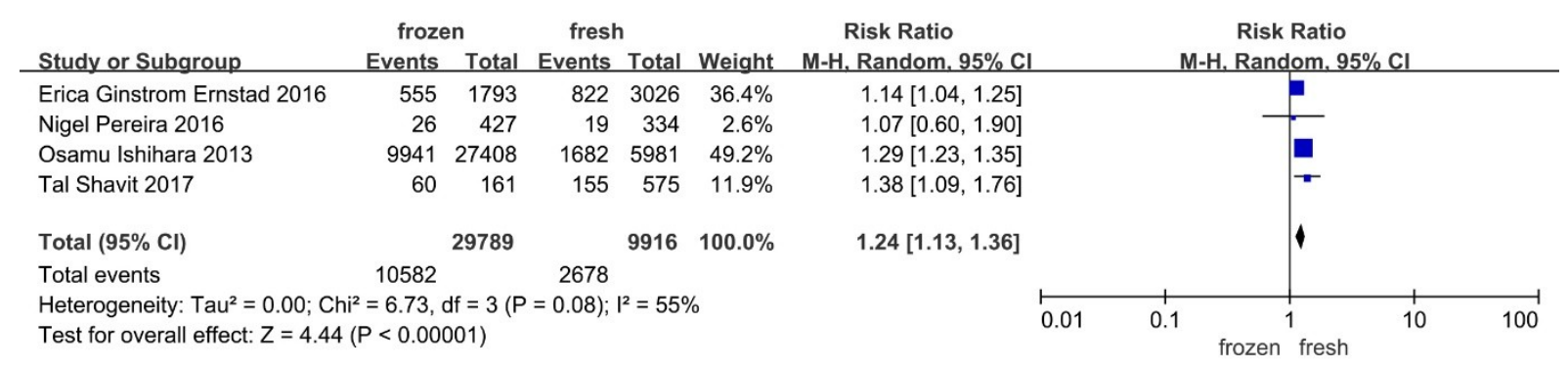

Figure 9. Comparison of frozen BT vs fresh BT on perinatal mortality

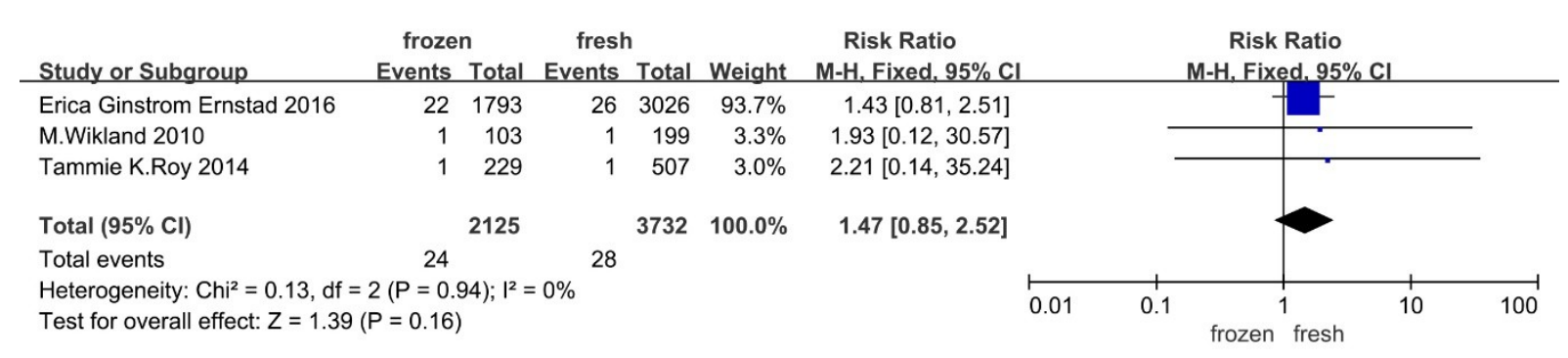

Figure 10. Comparison of frozen BT vs fresh BT on preeclampsia 


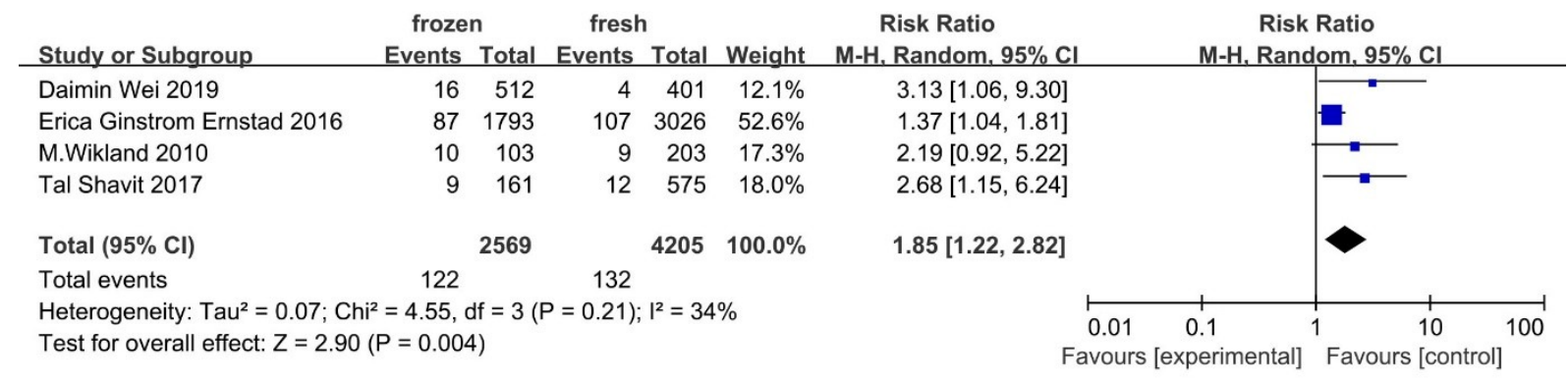

Figure S1.

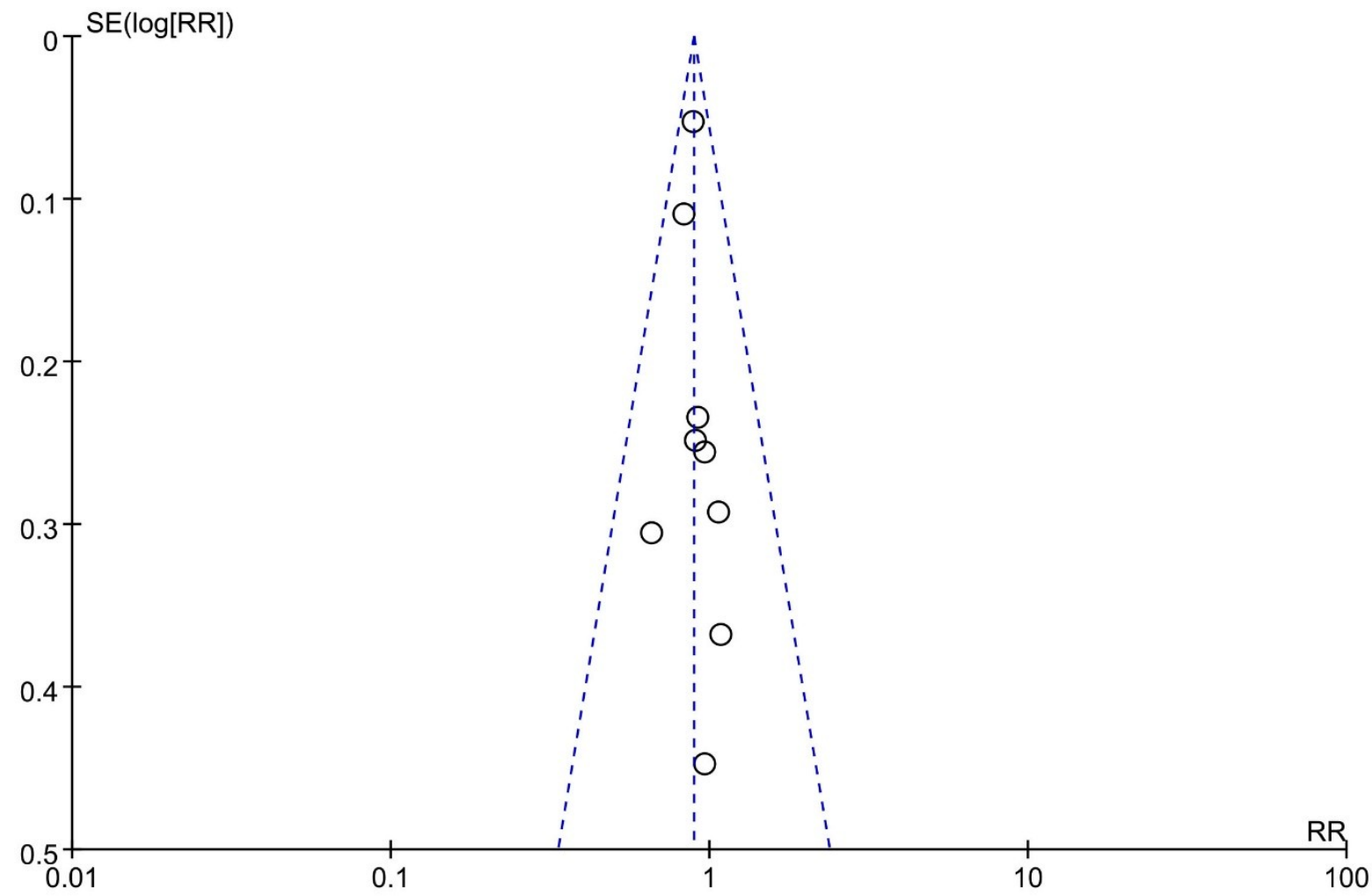

Figure S2. 


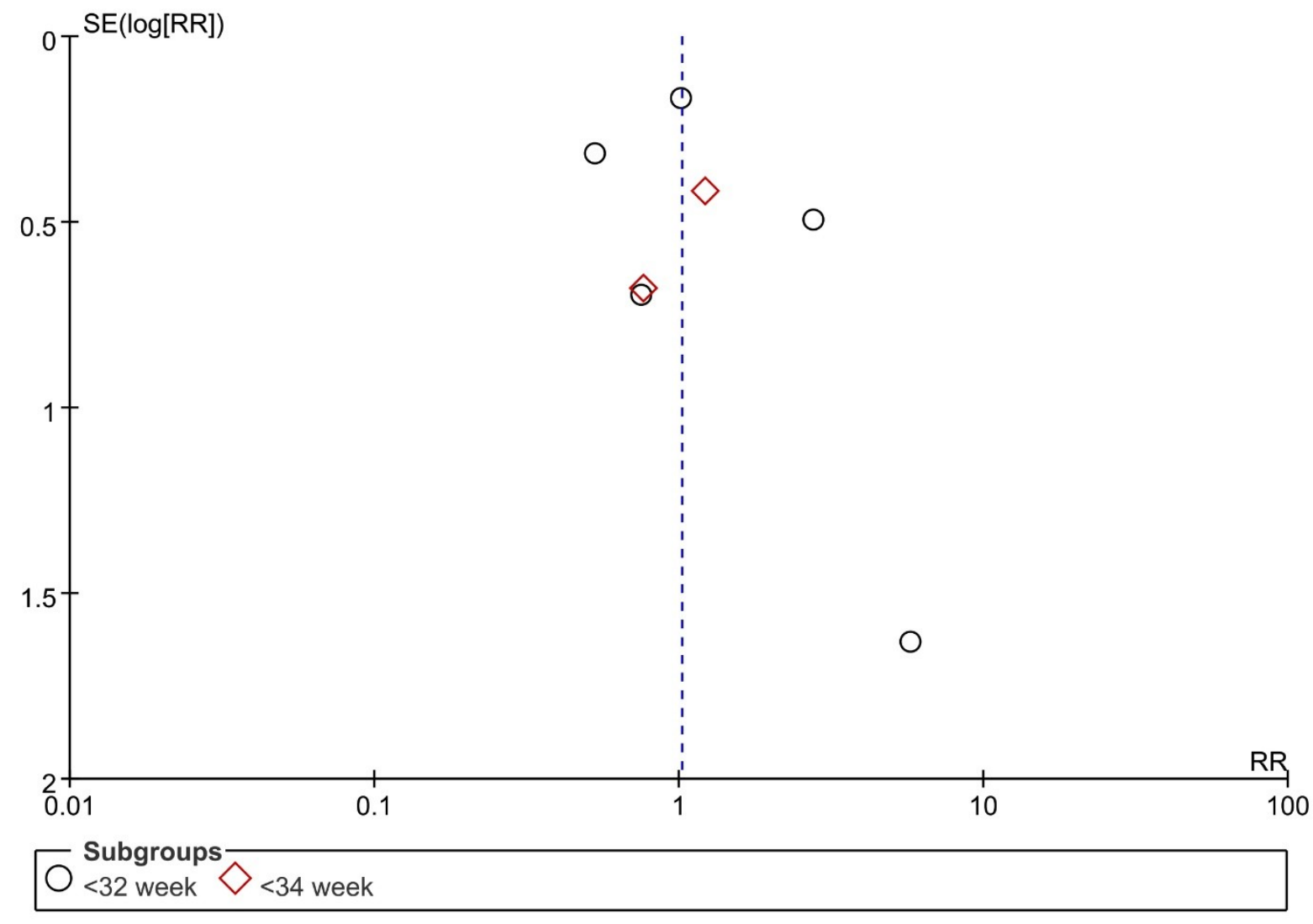

Fig. S3.

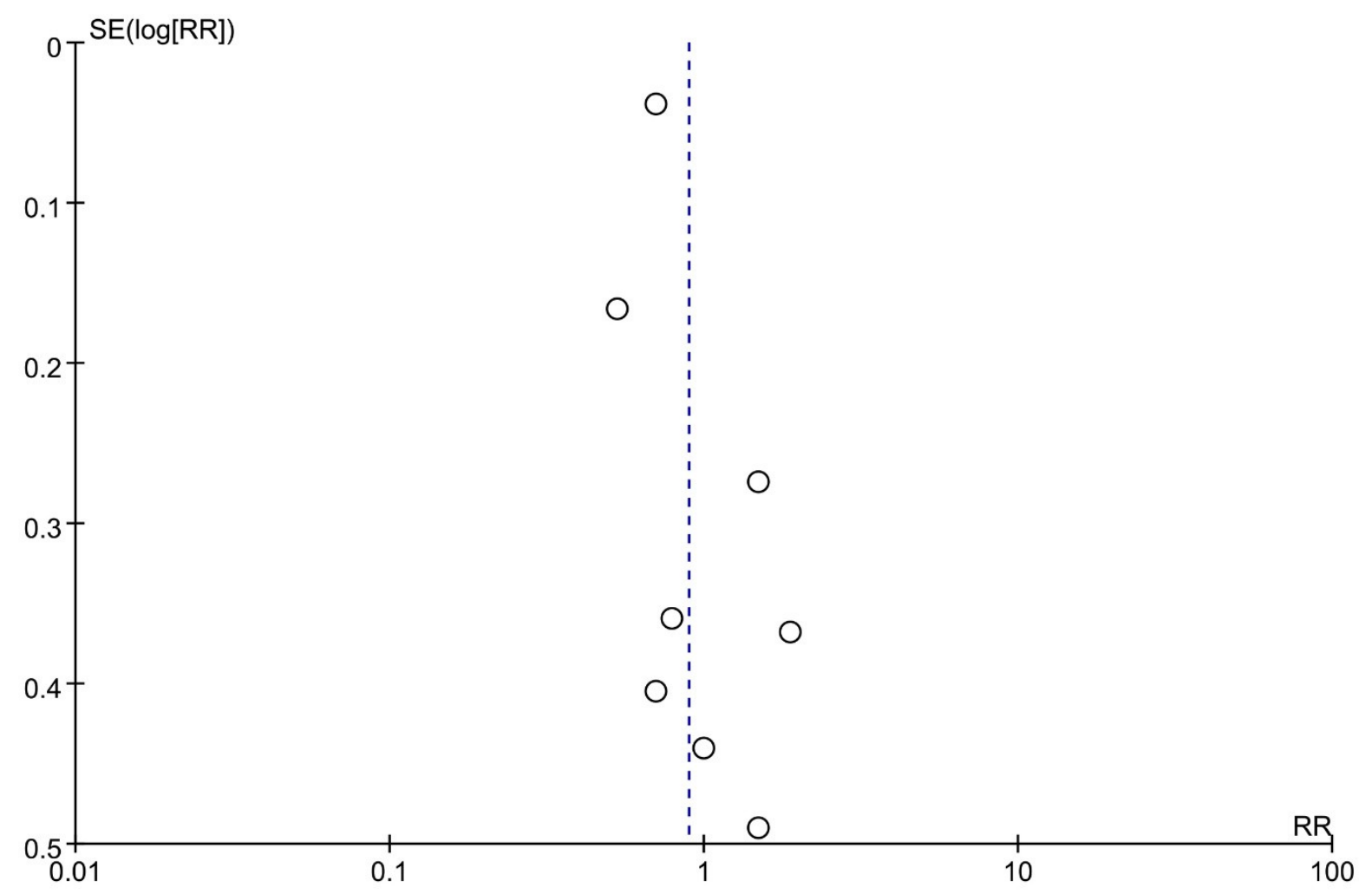


Figure S4.

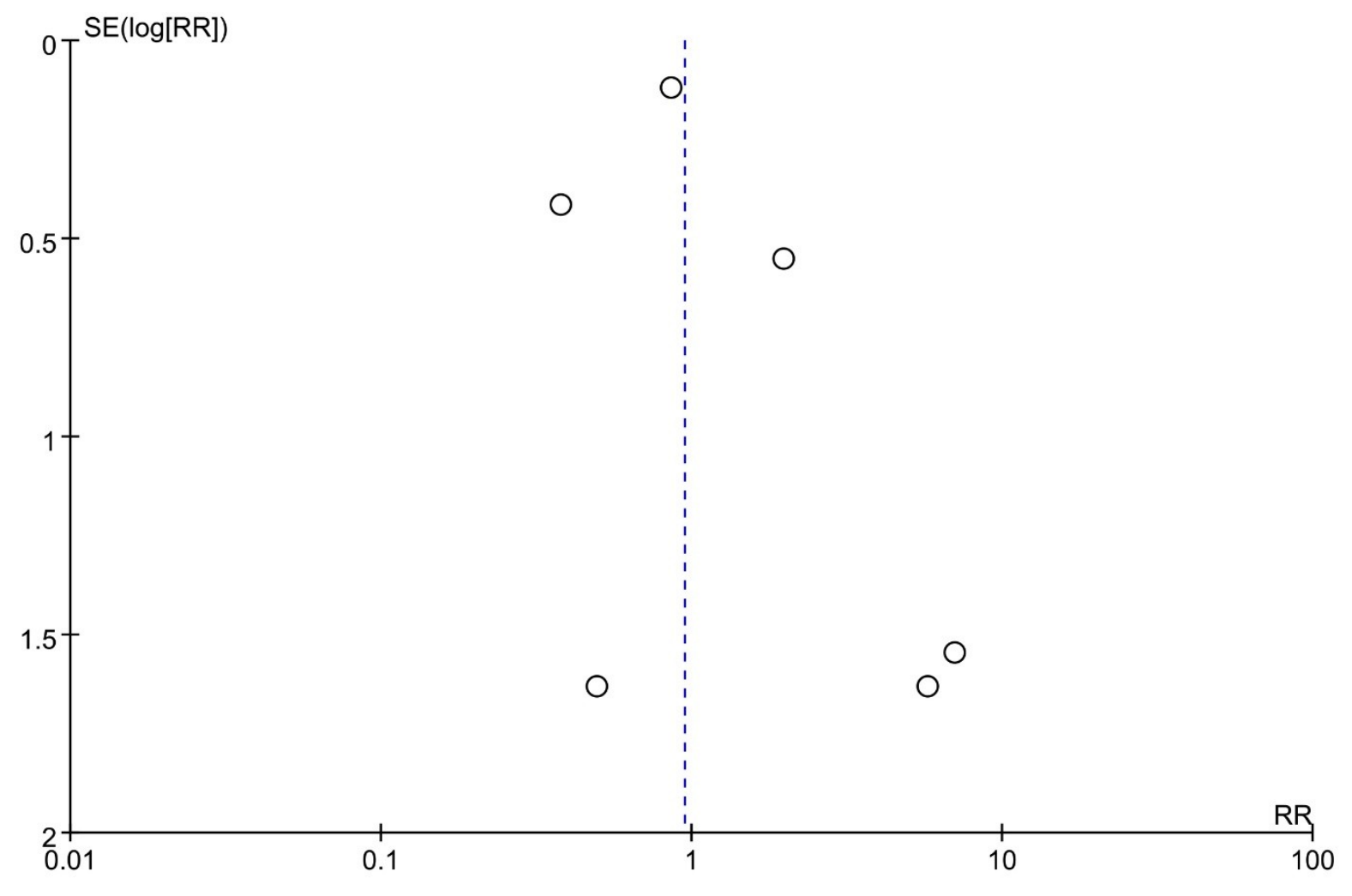

Figure S5.

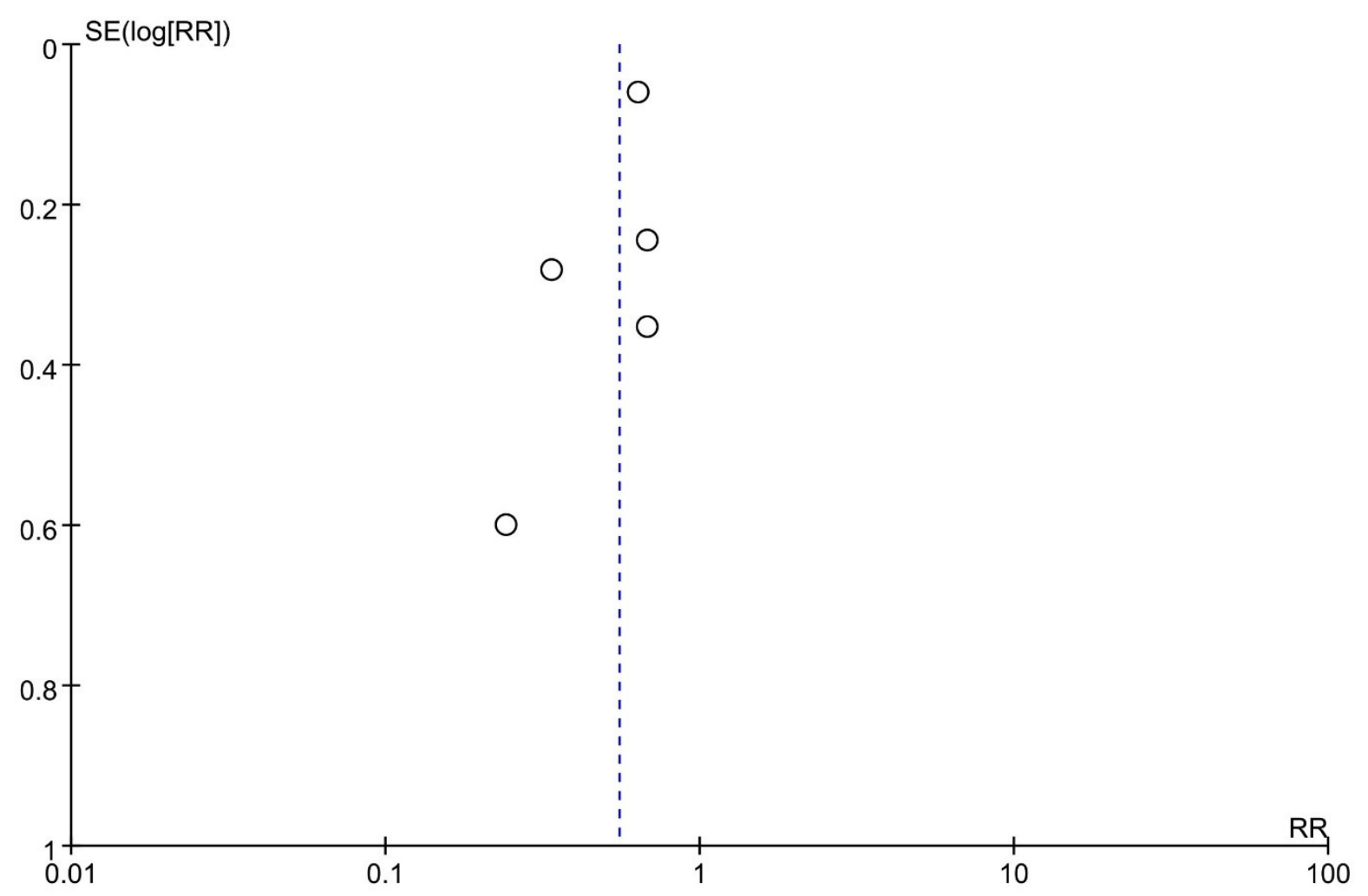

Figure S6. 


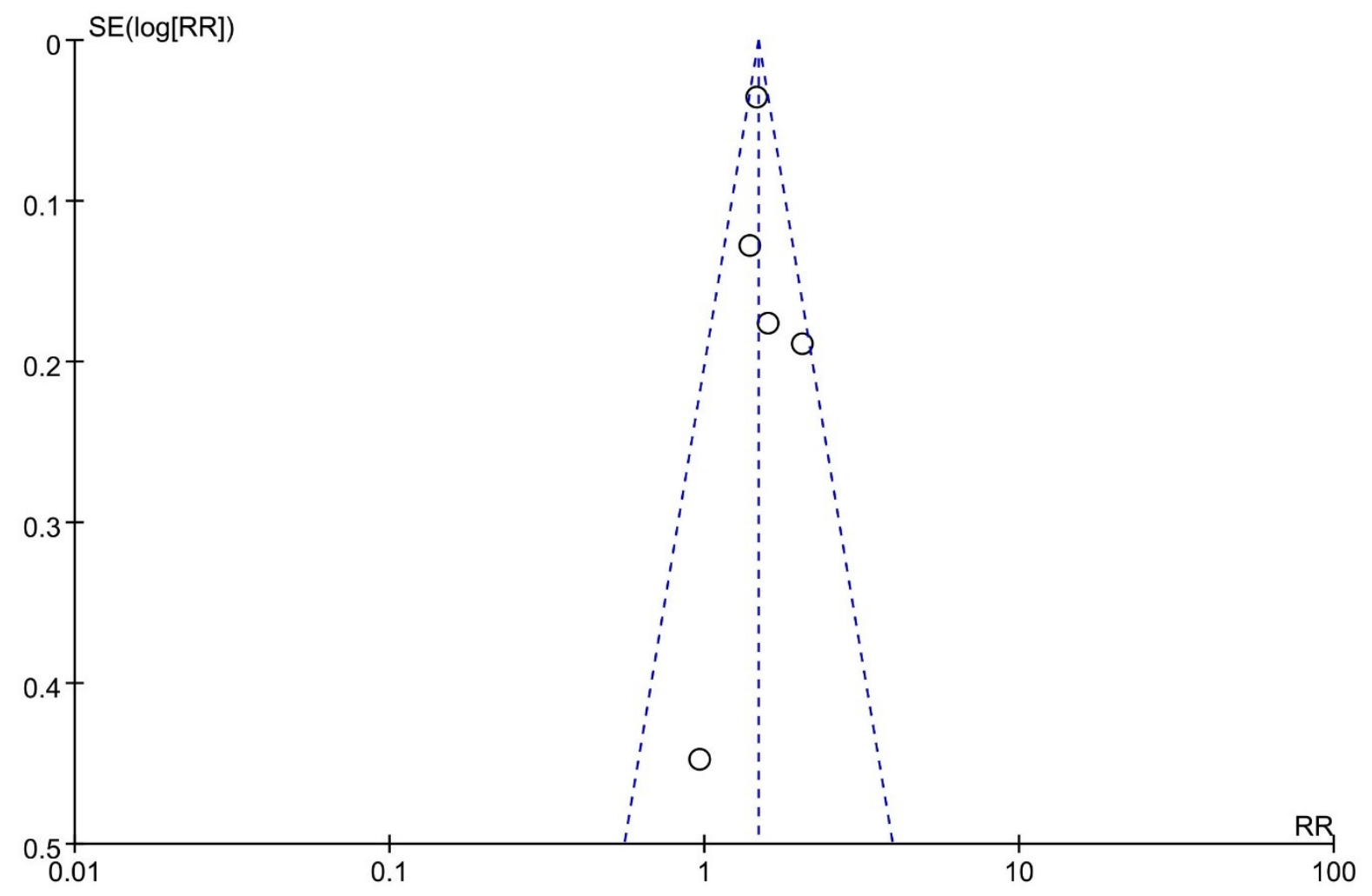

Figure S8.

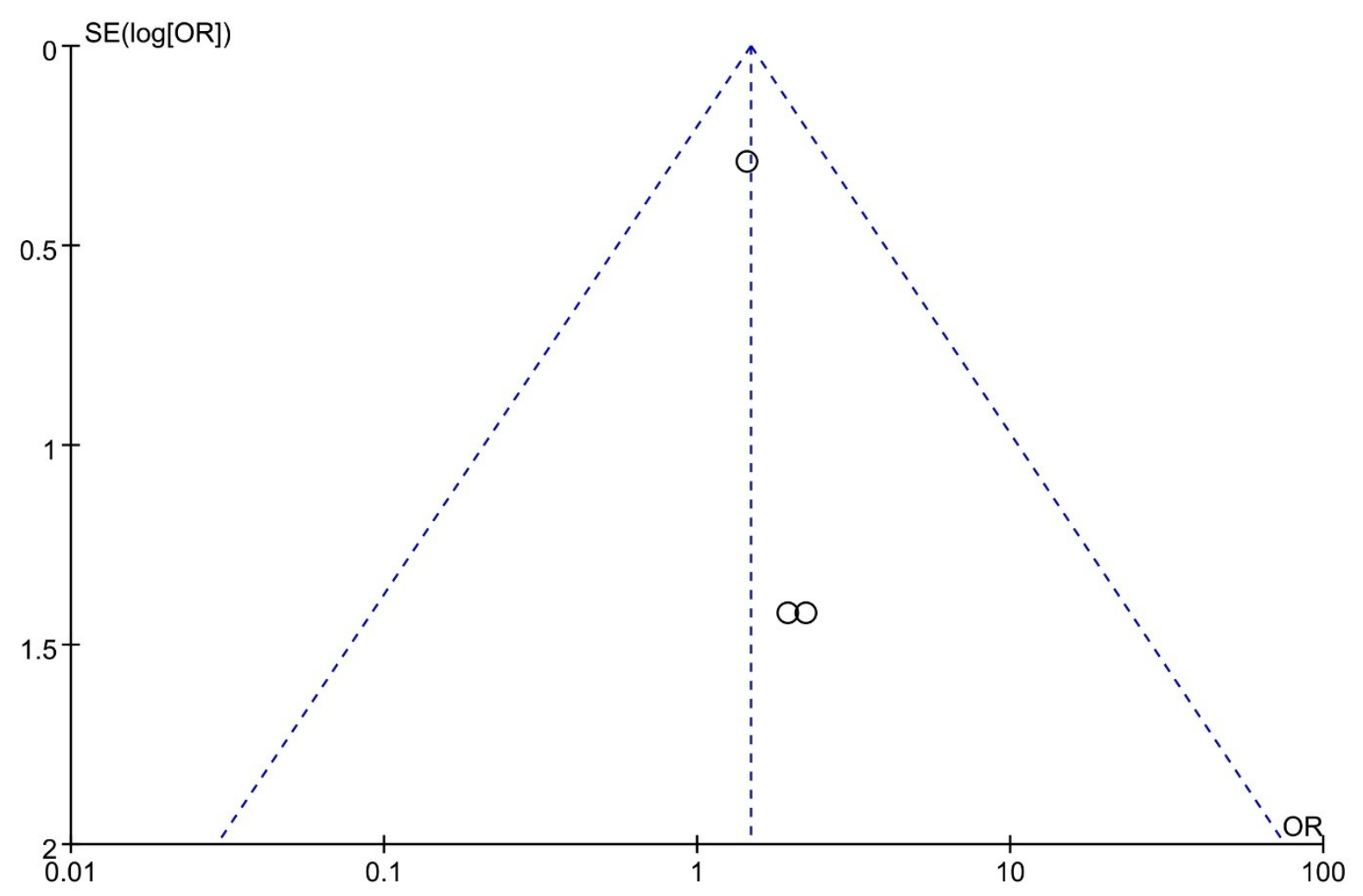


Figure S9.

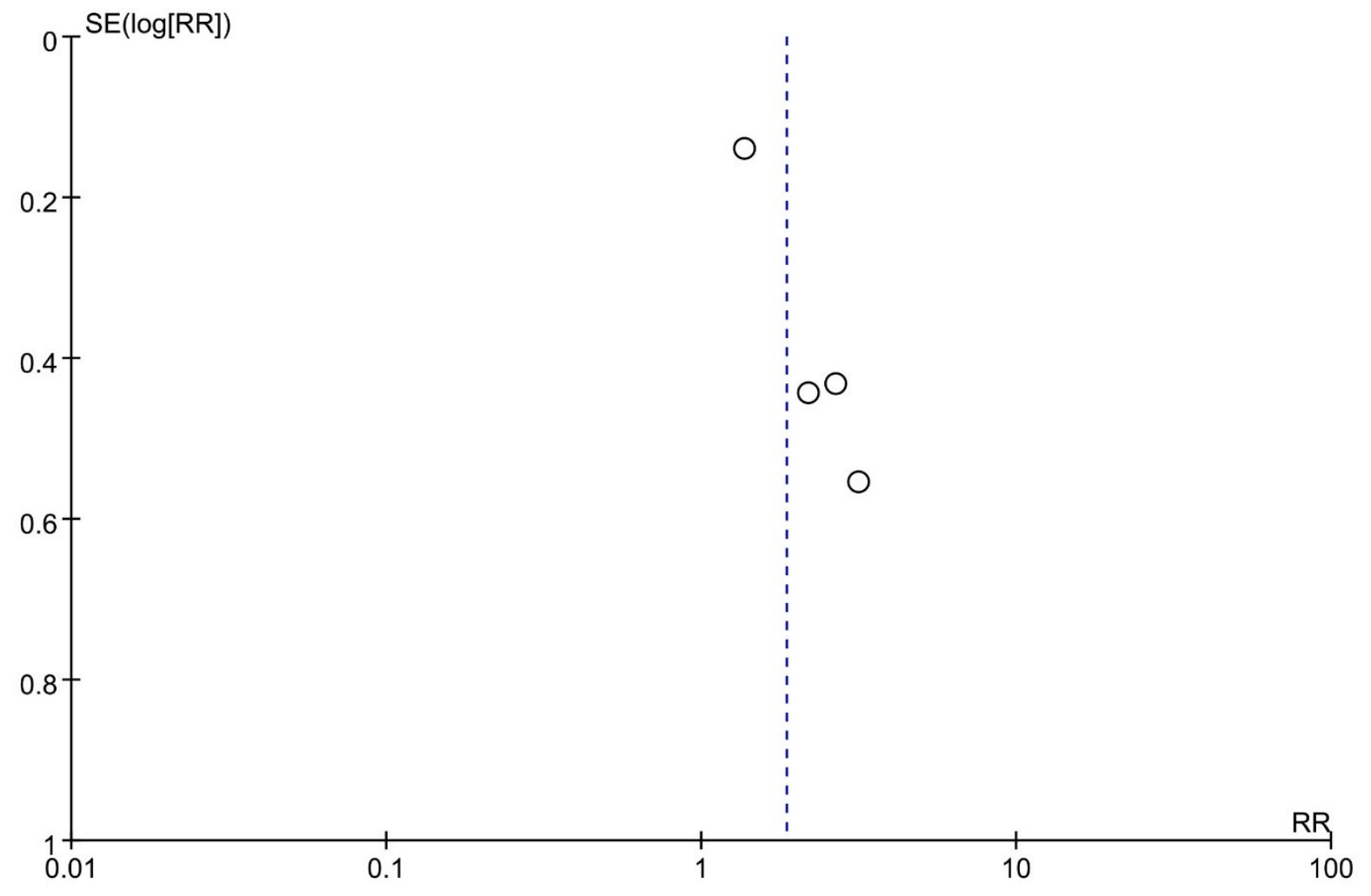

